\title{
Antelope bitterbrush seed production and stand age
}

\author{
CHARLIE D. CLEMENTS AND JAMES A. YOUNG
}

Authors are range scientists, USDA, Agricultural Research Service, 920 Valley Rd. Reno, Nev. 89512

\begin{abstract}
Antelope bitterbrush (Purshia tridentata (Pursh) DC) is the most important browse species on many western mule deer (Odocoileus hemionus) ranges. Lack of antelope bitterbrush seedling recruitment is a critical problem, and therefore, the influence of livestock grazing on antelope bitterbrush seed production is an important issue. Seed production was compared in grazed and ungrazed communities during 1995 and 1996 at 2 locations in northeastern California and one location in northwestern Nevada. A system of seed traps was used to estimate seed production in relation to the size, age and grazing of antelope bitterbrush plants in the various stands. Antelope bitterbrush seed production was significantly $(P \leq 0.01)$ higher at one of the ungrazed sites. Significant $(\mathbf{P} \leq \mathbf{0 . 0 5})$ differences in shrub ages were also recorded between sites.
\end{abstract}

Key Words: Purshia tridentata, mule deer, shrub, browse, herbivory

Antelope bitterbrush (Purshia tridentata (Pursh) DC) is one of the most important browse species on many western ranges. Fire, excessive grazing, insects, drought, and other unfavorable weather conditions can all contribute to the deterioration of antelope bitterbrush communities (Hormay 1943). Antelope bitterbrush is a key browse species in the diets of many mule deer (Odocoileus hemionus) herds (Lassen et al. 1952, Dasmann and Blaisdell 1954, Leach 1956, Updike et al. 1989). This shrub is also an important source of digestible protein for cattle (Bos taurus) during late summer and fall. The influence of domestic livestock grazing on wildlife habitat is a very important issue in northeastern California and throughout the west, thus antelope bitterbrush is a focal point in deer and cattle competition.

Antelope bitterbrush flowers on second year wood. Excessive utilization of the current annual growth is reported to reduce flowering and seed production the next season (Hormay 1943). However, the effects of livestock grazing on antelope bitterbrush seed production is not well known. This study was initiated to determine whether sites grazed by domestic livestock differed in antelope bitterbrush seed production from paired ungrazed sites of the same potential.

Authors would like to thank Robert Blank, Wayne Burkhardt, Steve Vander Wall, and 2 anonymous reviewers for helpful comments on the manuscript.

Manuscript accepted 16 Aug. 2000.

\section{Resumen}

El "Antelope bitterbrush" (Purshia tridentata (Pursh) DC) es la especie de ramoneo mas importante en muchos de los pastizales donde habita el "Western mule deer" (Odocoileus hemionus). La falta de establecimiento de plántulas de "Antelope bitterbrush" es un problema crítico, y por lo tanto, la influencia del apacentamiento del ganado en la producción de semilla de "Antelope bitterbrush" un problema importante. En 1995 y 1996 se comparó la producción de semilla en comunidades con y sin apcentamiento, la comparación se realizó en dos localidades del nordeste de California y en una localidad del noroeste de Nevada. Se utilizó un sistema de trampas semillas para estimar la producción de semilla en relación al tamaño, edad y apacentamiento en plantas de varias poblaciones de "Antelope bitterbrush". La producción de semilla del "Antelope Bitterbrush" fue significativamente mayor $(P \leq 0.01)$ en uno de los sitios sin apacentar. También se registraron entre sitios diferencias significativas $(P \leq 0.05)$ en la edad de los arbustos.

\section{Study Area}

We used 2 sites in northeastern California, and 1 site in extreme northwestern Nevada. The Turtle Mountain site, $40 \mathrm{~km}$ northeast of Doyle, Calif., is at an elevation of $1,378 \mathrm{~m}$, and has grazed and ungrazed communities. The ungrazed community is within a state wildlife management area that has been free from livestock grazing since 1948. The livestock-grazed community receives annual spring use by cattle. Both the grazed and ungrazed communities are dominated by antelope bitterbrush, big sagebrush (Artemisia tridentata ssp. tridentata Nutt.), and desert peach (Prunus andersonii A. Gray), with a cheatgrass (Bromus tectorum L.) understory. The soil is a gravelly, loamy, coarse sand. The site received $71 \mathrm{~cm}$ of precipitation from October of 1994 through October 1996, mostly during the winter months as recorded by rain gauges located on site.

The Buntingville, Calif., site is on private property $35 \mathrm{~km}$ south of Susanville, Calif. and received $150 \mathrm{~cm}$ of precipitation from October 1994 through October 1996, mostly during the winter months. The elevation is $1,345 \mathrm{~m}$. The grazed community is dominated by antelope bitterbrush, big sagebrush, and cheatgrass and receives late season grazing. The ungrazed community, separated from the grazed habitat by U.S. 395, is dominated by antelope bitterbrush with a very sparse occurrence of cheatgrass. The soils are a coarse gravel with inclusions of mixed loamy sand.

Pilgrim Lake in northwestern Nevada is $682 \mathrm{~km}$ north of Reno, Nev. at an elevation of $2,067 \mathrm{~m}$. The site has a three-way exclosure which was constructed in 1993 to protect 1 ha of habitat from livestock grazing. The site is dominated by antelope bitter- 
brush, mountain big sagebrush (Artemisia tridentata ssp. vaseyana Nutt.), and golden currant (Ribes aureum Pursh.), while the understory is dominated by Idaho fescue (Festuca idahoensis Elmer), bluebunch wheatgrass (Pseudoroegneria spicata [Pursh] A. Love.), and arrowleaf balsamroot (Balsamorhiza sagittata Pursh.). The site received $80 \mathrm{~cm}$ of precipitation from October 1994 through October 1996, mostly during the winter months. The soils are mostly clay with loamy inclusions. A 2 pasture deferred rest rotation grazing system by cattle is practiced on the unprotected habitat.

\section{Methods}

Antelope bitterbrush seed production was sampled in 1995 and 1996 on 10 randomly selected antelope bitterbrush shrubs in each grazed and ungrazed community. The same shrubs were used for both 1995 and 1996 sampling. The height of the shrub and diameter of the canopy of each shrub was measured.

Seed collecting grates measuring 9.5 $\mathrm{cm}^{2}$ surface area and $4.2 \mathrm{~cm}$ in depth were used to collect dispersed bitterbrush seeds for estimates of seed production. Four grates were evenly distributed under each bitterbrush shrub in the 4 cardinal directions $\left(38 \mathrm{~cm}^{2}\right.$ seed collecting grate area/shrub), $60 \mathrm{~cm}$ within the edge of the shrub, during the end of May of each year and marked by shrub, grazing treatment, and site. The grates, which allowed for seed collection but did not allow for seed predation by birds, rodents, and other seed predators, were picked up in mid-August following seed dispersal. Antelope bitterbrush seeds within individual grates were counted and recorded by shrub, site, and treatment. The number of antelope bitterbrush seeds produced by each shrub was calculated by multiplying the number of seeds in the seed trap by the proportionate area sampled $(\mathrm{N}=\mathrm{n} \times \mathrm{c}$, where $\mathrm{N}=$ total seed production, $\mathrm{n}=$ seeds in trap, $\mathrm{c}=$ canopy area sampled) using the seed trap method (Johnson and West 1988).

The height of the shrub, canopy (length $\mathrm{x}$ width), and basal diameter of the stem or trunk area of the 3 randomly selected antelope bitterbrush plants in each treatment were measured and the shrubs cut at the soil surface for age determinations. Growth rings were counted using a low power microscope to determine age (McConnell and Smith 1977).

A three-way, mixed Analysis of Variance model with repeated measures
Table 1. Antelope bitterbrush mean seed production ( \pm confidence interval) per shrub in 1995 and 1996 at 3 separate locations in grazed and ungrazed communities. Plants sampled per treatment $=10$.

\begin{tabular}{lccc}
\hline \hline $\begin{array}{l}\text { Location/ } \\
\text { Treatment }\end{array}$ & Year & $\begin{array}{c}\overline{\mathrm{x}} \\
\text { Seed Production }\end{array}$ & $\begin{array}{c} \pm 95 \% \text { Confidence } \\
\text { Interval }\end{array}$ \\
\hline Buntingville & & ( seeds/plant) \\
Grazed & 1995 & 8,700 & 2,515 \\
Ungrazed & 1996 & 24,000 & 10,504 \\
& 1995 & 90,600 & 18,833 \\
Turtle Mountain & 1996 & 28,500 & 5,485 \\
Grazed & & & \\
Ungrazed & 1995 & 6,200 & 1,989 \\
& 1996 & 6,600 & 1,657 \\
Pilgrim Lake & 1995 & 4,400 & 1,236 \\
Grazed & 1996 & 8,800 & 1,301 \\
Ungrazed & & & \\
& 1995 & 700 & 243 \\
& 1996 & 2,000 & 390 \\
& 1995 & 900 & 360 \\
& 1996 & 2,500 & 1,076 \\
\hline
\end{tabular}

was used to analyze the effects of grazing, site, and year on seed productivity.

\section{Results}

Antelope bitterbrush seed production was significantly greater $(\mathrm{P} \leq 0.01)$ at the Buntingville ungrazed treatment in 1995 compared to all other sites and treatments (Table 1). The remaining treatments were not significantly different among treatments (grazed or ungrazed), and years, but

there was a significant $(\mathrm{P} \leq 0.05)$ difference in seed production between sites. Antelope bitterbrush seeds at the Buntingville site produced significantly ( $\mathrm{P}$ $\leq 0.05)$ more seeds than recorded at the Turtle Mountain and Pilgrim Lake sites, and Turtle Mountain significantly ( $\mathrm{P} \leq$ $0.05)$ produced more seeds than did the Pilgrim Lake site.

The age of antelope bitterbrush shrubs was significantly $(\mathrm{P} \leq 0.05)$ older at the Pilgrim Lake and Turtle Mountain sites than the Buntingville site (Fig. 1). The

\section{BITTERBRUSH}

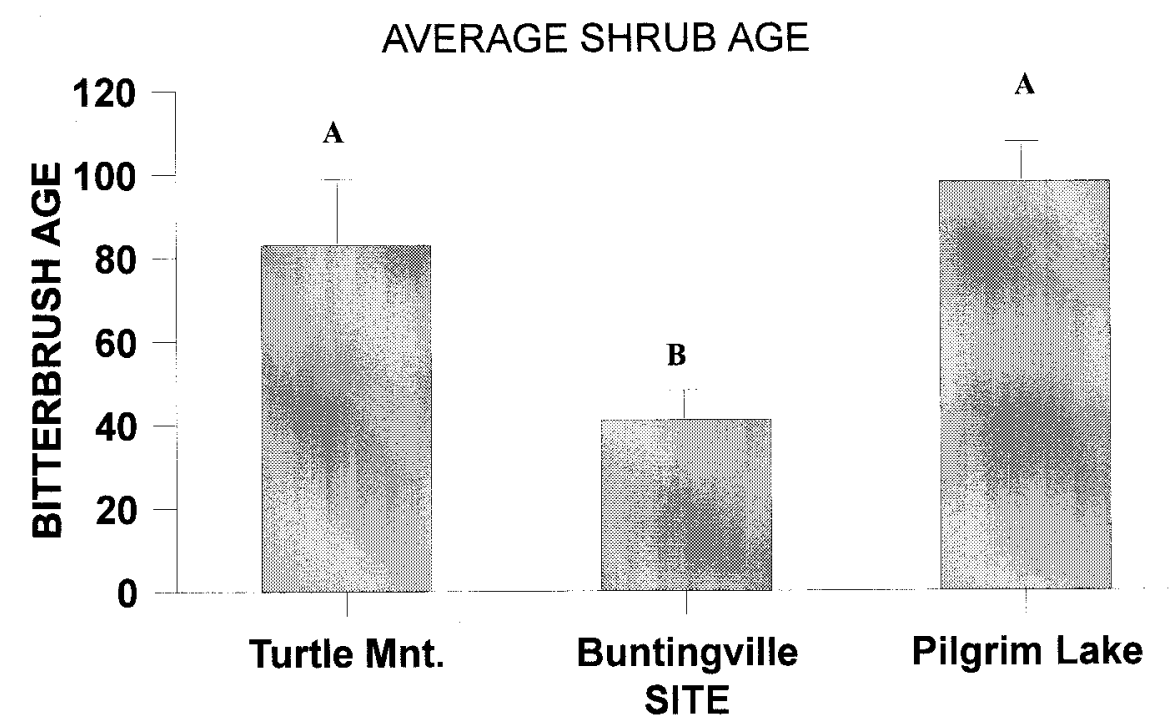

Fig. 1. Average age of antelope bitterbrush shrubs. Sites with same letter are not significantly different $(P>0.05)$. 


\section{BITTERBRUSH}

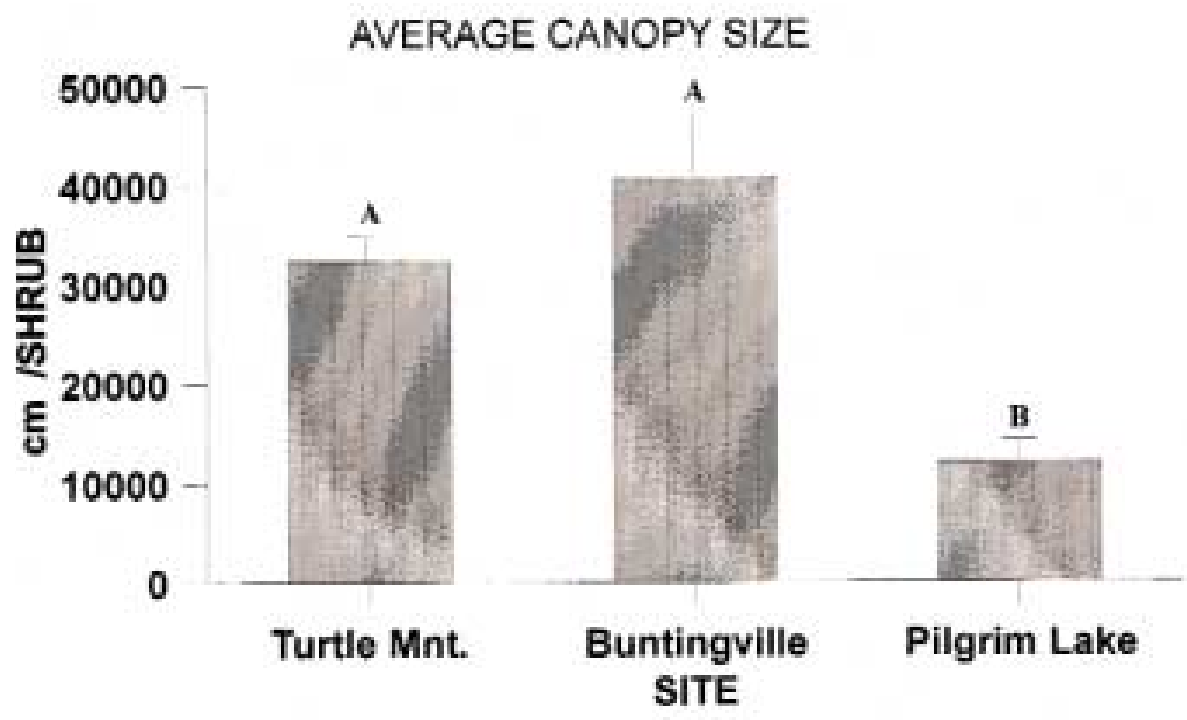

Fig. 2. Average canopy size of antelope bitterbrush shrubs. Sites with same letter are not significantly different $(P>0.05)$.

Buntingville ungrazed habitat was significantly $(\mathrm{P} \leq 0.05)$ younger $(\overline{\mathrm{x}}=33)$ than the other grazed and ungrazed habitats ( $\mathrm{n}$ $=5)$, including the Buntingville grazed habitat $(\overline{\mathrm{x}}=49)$.

There was no significant difference in the height of antelope bitterbrush shrubs between these sites and treatments. However, antelope bitterbrush shrubs had significantly $(\mathrm{P} \leq 0.05)$ lower mean canopy diameter at the Pilgrim Lake site than that recorded at the Turtle Mountain and Buntingville sites (Fig. 2).

\section{Discussion}

The Buntingville ungrazed community produced almost twice as much antelope bitterbrush seed per shrub monitored in 1995 than in 1996. This greater seed production was the only statistical difference in antelope bitterbrush seed production between treatments and years during the study. Precipitation is a major role player in antelope bitterbrush seed production (Nord 1965). The site received $74 \mathrm{~cm}$ of precipitation from October 1994 to October 1995, which is $45 \%$ more precipitation than it received from October 1995 to October $1996(41 \mathrm{~cm})$. The amount and periodicity of moisture received should generally effect the adjacent grazed and ungrazed treatments equally, but some confusing occurrences took place. Antelope bitterbrush plants flower on sec- ond year wood, therefore precipitation the previous year is very important. Antelope bitterbrush shrubs in the grazed community at the Buntingville site produced $36 \%$ more seeds in the less favorable precipitation scenario of 1996 than it did in 1995 during a more favorable scenario. The Buntingville grazed site experienced improved seed production through the favorable precipitation scenario. The importance of this relation in interpreting the results of this study is that grazing did not reduce the excellent shoot growth in 1995 enough to depress seed production in 1996 at the Buntingville site. The height and crown diameter of the antelope bitterbrush plants at the Buntingville grazed site places much of the current annual twig growth out of the reach of grazing animals. This is one of the multitude of factors that influences the relative influence of livestock grazing on antelope bitterbrush seed production.

Appearance of antelope bitterbrush plants can be deceiving in terms of actual age. The Buntingville grazed and ungrazed communities appear to be very different in age, but based on analysis of trunk growth rings, the grazed community was 16 years older, 33 years of age in the ungrazed community and 49 years of age in the grazed community, respectfully. This 16 year difference in age should not play a major role in the difference in seed production between the two treatments at the Buntingville site we experienced, and therefore may suggest that the level of grazing on antelope bitterbrush shrubs over time between the two treatments plays a larger role in the seed production results we recorded. Foliage production of antelope bitterbrush is reported by McConnell and Smith (1977) to peak at around 60 years of age with early season grazing. The Buntingville site was the only site under 60 years of age. The Turtle Mountain site averaged 83 years of age and the Pilgrim Lake site averaged 98 years of age. Using McConnell and Smith's (1977) estimates on the peak production of antelope bitterbrush, the age classes at two of our three sites were well past their peak in production. This can result in an inadequate seed source at the site, thus poor seedling recruitment may result, as is currently being reported.

The Buntingville site is in the heart of the antelope bitterbrush communities where the Lassen cultivar was selected. The once continuous stands of large statured plants have been broken into smaller units in the Buntingville area by increasing development of home sites. It is very possible the stands on adjoining sides of a major highway resulted from separate stand renewal processes, perhaps wildfires.

Great Basin tent caterpillar (Malacosoma fragile) infestations occurred at the Buntingville and Pilgrim Lake sites during 1996. This caterpillar periodically infests bitterbrush causing defoliation and sometimes death (Clark 1956, Furniss and Barr 1975). The stress these caterpillars inflicted upon these shrubs can result in significant loss of foliage and seed production. The accumulations of tent caterpillar webs and debris have a negative influence on herbivore preference for the browse. We assume the chances of infestation are equal between grazed and ungrazed sites, but in the case of the Buntingville site this may not be true, as we noted a heavier infestation of the tent caterpillar at the Buntingville ungrazed community in 1996 than that in the grazed habitat. This may have played a factor in the decreased seed production experienced at the Buntingville ungrazed community from 1995 to 1996.

The Buntingville ungrazed community was visually more vigorous than plants at the other sites or treatments (Fig. 3a and 3b.). This ungrazed community is also along U.S. 395, a very heavily traveled highway creating a barrier to mule deer movement. The combination of factors such as minimal herbivory, favorable precipitation, and younger age class may all 


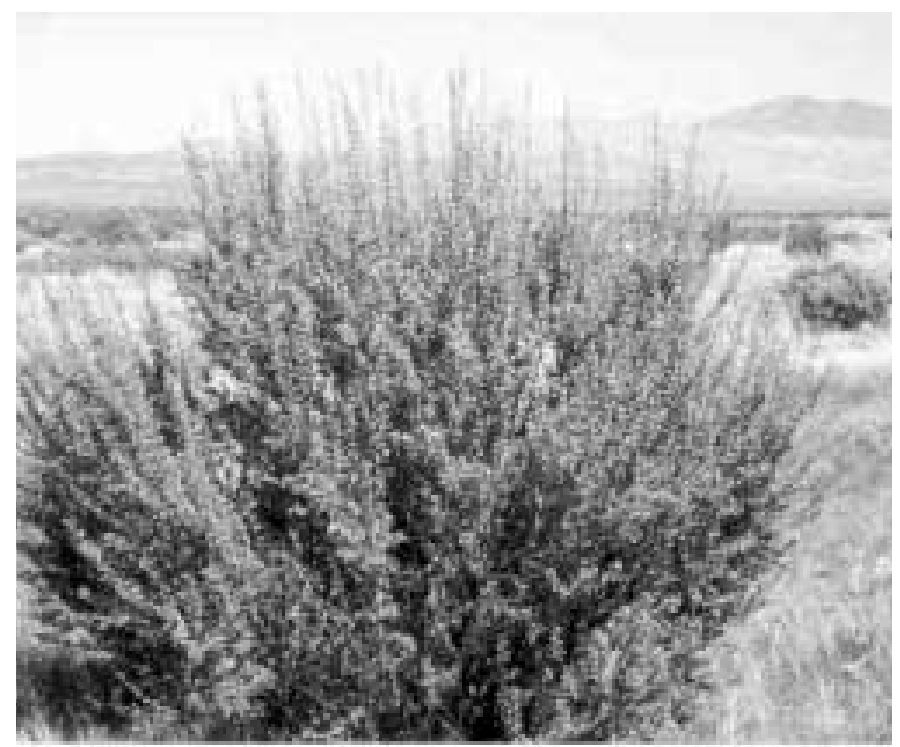

a

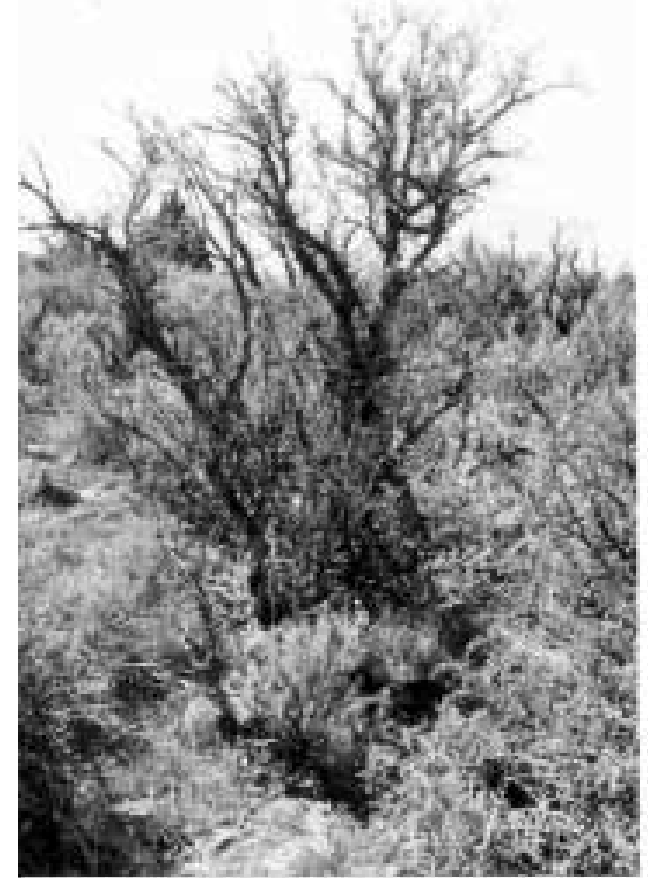

b

Fig. 3. Notice the leader length of this younger more vigorous antelope bitterbrush shrub (a) compared to an old decadent shrub (b).

help in making the Buntingville ungrazed community significantly more productive, although insect herbivory greatly curtailed this productivity in 1996.

This study suggests that grazing had an effect (negative effect) on antelope bitterbrush seed production at one site. This one site was also a younger more vigorous antelope bitterbrush community. But, the poor age distribution (older age class shrubs) of antelope bitterbrush shrubs suggests that recruitment of younger antelope bitterbrush shrubs into bitterbrush communities has been lacking for some time (80100 years). Removal of livestock itself may not increase bitterbrush foliage production and second year growth, or seed production, but may rather add stress to the plant thus decreasing its years in sustainable production as reported by McConnell and Smith (1977). The Turtle Mountain and Pilgrim Lake grazed plant communities received light grazing during this study, while the Buntingville grazed community received moderate levels of use. Adams 1975, reported that in southern Oregon an antelope bitterbrush community that averaged 473 antelope bitterbrush shrubs per 0.4 hectares, required the establishment of 6.7 antelope bitterbrush plants per 0.4 hectares annually to propagate the community. He also reported that the establishment of antelope bitterbrush plants into the community from 1925 to 1975 was 0.7 plants per 0.4 hectares annually, resulting in old even-aged decadent antelope bitterbrush communities.

Outside of seed production, other factors that influence the establishment of antelope bitterbrush plants into the community include seed damage by insects (Furniss 1972), seed predation by granivorous rodents (Clements 1994), seed dispersal by granivorous rodents (Vander Wall 1994), seedling competition with other plant species (Holmgren 1956), seedling predation by rodents (Clements and Young 1996) and insects (Hubbard 1956), and grazing by domestic and wild animals (McNulty 1947), to name a few.

The establishment of new antelope bitterbrush plants into the community is very complex, and with all the research done in the area of antelope bitterbrush ecology, researchers as well as resource managers are still unsure of the importance of the various factors on antelope bitterbrush seedling establishment. Bitterbrush is an opportunistic species, perhaps the propagation of this species is highly dependent on some form of habitat manipulation or combinations of manipulation. Senescent antelope bitterbrush shrubs lose vigor and provide little browse.

Leopold (1959) suggested to the Nevada Department of Fish and Game that to maintain high carrying capacities of mule deer, deliberate manipulation of habitat must be implemented. At both the Turtle Mountain and Pilgrim Lake sites, the age classes of antelope bitterbrush suggest that any form of natural disturbance for propa- gating antelope bitterbrush has been absent for the past $80-100$ years. The Buntingville site is of a younger age class and both the grazed and ungrazed communities are under private ownership. Though no absolute deliberate disturbance is documented, being under private ownership may have resulted in such a disturbance that favored antelope bitterbrush recruitment. The widespread concern over the lack of antelope bitterbrush recruitment on many western rangelands warrants further research on this problem. Further research into the effects of livestock as well as native herbivores on antelope bitterbrush seedlings, as well as investigating different methods of vegetation manipulation to reinvigorate bitterbrush and other brush communities is an area of research worth approaching.

\section{Literature Cited}

Adams, A. W. 1975. A brief history of juniper and shrub populations in southern Oregon. Oregon State Wildl.Comm.Wildl. Res. Rep. 6. Corvallis, Ore. 33 p.

Clark, E. C. 1956. The Great Basin tent caterpillar in relation to bitterbrush in California. California Fish and Game 42:131-141.

Clements, C. D. 1994. Influence of rodent predation on antelope bitterbrush seeds and seedlings. Thesis. Univ. of Nevada Reno. pp 49. Reno, Nev.

Clements, C. D. and J. A. Young. 1996. Influence of rodent predation on antelope bitterbrush seedlings. J. Range Manage. 49:31-34. 
Dasmann, W. P. and J. A. Blaisdell. 1954. Deer and forage relationships on the LassenWashoe interstate winter deer range. California Fish and Game 40(3):215-234

Furniss, M. M. 1972. Entomology of antelope bitterbrush. Pp.164-172. In: Gen. Tech Rept. INT. 152. USDA, Forest Service, Ogden, Ut.

Furniss, M. M. and W. F. Barr. 1975. Insects affecting important shrubs of the northwestern United States. Gen. Tech. Rept. INT 19. USDA, Forest Service, Intermountain Forest and Range Expt. Sta. Ogden, Ut. 64 p.

Holmgren, R. C. 1956. Competition between annuals and young bitterbrush (Purshia tridentata) in Idaho. Ecol. 37:370-377.

Hormay, A. L. 1943. Bitterbrush in California. USDA, Forest Service, California Forest and Range Expt. Sta. Res. Note No.34, USDA, Forest Serv., Berkeley, Calif.
Hubbard, R. L. 1956. Bitterbrush seedlings destroyed by cutworms and wireworms. Res. Note 114. USDA Forest Service, Berkely, Calif.

Johnson, C. K. and N. E. West. 1988. Laboratory comparisons of five seed-trap designs for dry, windy environments. Can. J. Bot. 66:346-348.

Lassen, R. W., C. M. Ferrel and H. Leach. 1952. Food habits, productivity and condition of the Doyle mule deer herd. California Fish and Game 38(3):211-224.

Leach, H. R. 1956. Food habits of the Great Basin deer herd of California. California Fish and Game 42(3):243-308.

Leopold, A. S. 1959. In survey of Fish and Game problems in Nevada. Nevada Legislative Counsel Bur. Bull. \#36. Carson City, Nev.
McConnell, B. R. and J. G. Smith. 1977. Influence of grazing on age-yield interactions in bitterbrush. J. Range Manage. 30:91--93.

McNulty, I. B. 1947. The ecology of bitterbrush in Utah. M.S. Thesis, Utah State University, Salt Lake City, Ut.

Nord, E. C. 1965. Autecology of bitterbrush in California. Ecol. Monogr. 35:307-334.

Updike, D. R., E. R. Loft and F. A. Hall. 1989. Wildfires on big sagebrush/antelope bitterbrush range in northeastern California: Implications for deer populations. In: S. B. Monsen, and S. G. Kitchen (ed.) Proc. Ecology and Management of Annual Rangelands. Gen. Tech. Rept. 313. USDA, Forest Service, Ogden, Ut.

Vander Wall, S. B. 1994. Dispersal and establishment of antelope bitterbrush by seed caching rodents. Ecol. 17:1911-1926. 